\title{
The problem of social security of residents of rural areas of Russia in modern conditions: social and philosophical dimension
}

\author{
Andrey Shilovtsev ${ }^{1,}$, , Natalia Sorokina ${ }^{1}$, Konstantin Stozhko ${ }^{1}$, and Jose Luis Lopez Garcia ${ }^{2}$ \\ ${ }^{1}$ Ural State Agrarian University, 620075, Karl Liebknecht str., 42, Yekaterinburg, Russia \\ ${ }^{2}$ Universidad Poltecnica de Madrid, Ramiro de Maeztu, 7, 28040 Madrid, Spain
}

\begin{abstract}
The article considers the problem of social security of rural residents from a socio-philosophical point of view in the context of the need to further strengthen it and improve the entire system of social and labor relations. The morphology of social security and its features in the conditions of modern agricultural production are revealed. Identified shortcomings of existing calculation of the minimum wage (SCMW) and the minimum subsistence level (MSL) as a factor in their failure to comply with the required level of social security of the rural population. The main causes and forms of devaluation of social security in rural areas (underdevelopment of industrial and social infrastructure, migration of rural population to megacities, etc.) are identified. Measures are proposed to strengthen the social security of the rural population, taking into account all its components.
\end{abstract}

\section{Introduction}

The relevance of the study of social security of the individual agricultural workers, as a special case of a more General problem of improving social security of the individual in the context of growing macroeconomic instability, is relevant for a number of reasons.

First, the deterioration of the demographic situation in the country, which was highlighted in his last Message to the Federal Assembly by President of the Russian Federation Vladimir Putin (2020). The annual population loss according to official data is about 400 thousand people.

Second, the growing migration of rural residents to megacities and cities. as a result, the population of the village is decreasing, and there is a growing shortage of personnel to work in the village.

Third, the growing urgency of the problem of ensuring food security in our country, in the context of ongoing economic sanctions against us by certain Western countries and unfair competition.

\footnotetext{
*Corresponding author: a.shilovtsev@mail.ru
} 
The purpose of the study is to assess the level and quality of social security of rural residents in the Russian Federation based on the analysis of the reasons for its decline and determine the main directions for its improvement.

\section{Materials and methods (Knowledge of the problem and research methodology)}

The problem of social security of rural residents has received considerable attention in recent decades. Among the works of recent years we can mention the research of A. A. Bykov, U. A. Vinokurova, E. E. Elshina, V. V. Lesnykh, N. V. Prokhorova, B. A. Revich, R. M. Sadykov, N. N. Tikhonov, R. G. Yanovskij and others.

Special attention is paid to understanding the relationship problems of social security in rural areas and sustainable development of the Russian economy (T. V. Alferov, E. N. Bazarkina, B. E. Bolshakov, V. S. Hnatiuk, H. N. Gizatullin, O. I. Mitakova, E. C. Sadykov, E. A. Tretyakov, F. H. Tshurbaev, etc.).

However, a holistic and systematic approach to this problem still remains undeveloped due to the lack of conceptual generalizations and socio-philosophical reconstruction of the phenomenon of social security of rural residents.

We need to clarify the concepts of "social security", "rural territory"," resident of rural territory", which are interpreted differently by different authors. Within the framework of this research, the authors propose to understand the term "social security of a person" not just as a state of his protection from external threats and risks, but, primarily, as a condition when a person is able to independently ensure his safety, make and implement appropriate decisions, and deliver on his subjective potential. Similarly, it is proposed to clarify the understanding of "rural areas", which, according to the "Concept for sustainable development of rural areas" developed by the Ministry of Agriculture of the Russian Federation, are understood as rural settlements or "inter-settlement territories" within the boundaries of a municipal district or included in urban districts, "which territories are dominated by activities related to the production and processing of agricultural products". Obviously, abandoned territories (former villages and settlements) should also be classified as "rural areas", despite the fact that residents have left them or regular business activities are not conducted.

Accordingly, "residents of a rural area" are all those who live in any rural area (both included in the economic turnover and not included in it). Such an "expanded" interpretation of the concepts allows covering all territories and all categories of the country's population, avoiding their "escheated" interpretation.

The research uses methods of structural-functional, program-target and dialectical analysis. The subject of the research is the essence, content and quality of social security in rural areas. The object of research is the system of social and labor relations in the field of agriculture.

\section{Results and discussion (the results of the study)}

The In modern science, a discrete approach to the problem of social security prevails. Different authors study different forms of social security (political, economic, psychological, cultural, informational, environmental, etc.), but in a certain sense ignore the features of setting and solving this problem in different climatic and geopolitical conditions. In particular, the problem of social security of rural residents is considered in the context of solving the more General problem of improving the social security of the population of the Russian Federation as a whole. This is done without the necessary specification and detail 
of the problem. In addition, as it is rightly noted in the literature, the studied territory of our country was divided into "scraps", and more than a third of its territory is devoid of any infrastructure and is not studied by anyone [1, p.139].

On the other hand, rural areas in our country in most cases are polluted and not safe, not suitable for safe living. They are called " kakosfera "(from the Greek - "bad") [2, p. 627], in contrast to the" ecosphere "(from the Greek - "house","home"). The criteria for dividing all rural territories into these two areas are still far from universal and rather vague. Including those that relate to the social aspects of security. In particular, the level and quality of life of the rural population.

There is still little research in the field of socio-philosophical and sociological understanding of social security in rural areas, since the mass migration of the rural population to cities and the growth of urban economy leave this aspect of the problem on the periphery of scientific research.

\subsection{Research result}

Social security is a necessary degree of protection of a person from various types of risks, instability and threats. The measure of such protection is determined by the scale of objective economic interests and needs of the individual and society, without which it is impossible to expand their reproduction. There are different aspects of social security: political, economic, environmental, cultural, informational, food, etc. In a generalized form, the social security of rural residents can be represented in the form of a matrix (table 1):

Table 1. Social security of rural residents

\begin{tabular}{|c|c|c|c|}
\hline $\begin{array}{c}\text { Social security } \\
\text { module for rural } \\
\text { residents }\end{array}$ & $\begin{array}{c}\text { System for providing } \\
\text { a specific social } \\
\text { security module }\end{array}$ & $\begin{array}{c}\text { Criteria for the } \\
\text { quality of life of rural } \\
\text { residents }\end{array}$ & $\begin{array}{c}\text { Directions of social } \\
\text { security } \\
\text { development }\end{array}$ \\
\hline economic & $\begin{array}{c}\text { agro-industrial } \\
\text { complex system }\end{array}$ & $\begin{array}{c}\text { employment } \\
\text { (unemployment) }\end{array}$ & $\begin{array}{c}\text { income growth of } \\
\text { rural residents }\end{array}$ \\
\hline social & $\begin{array}{c}\text { the system of social } \\
\text { protection of the } \\
\text { population rural areas }\end{array}$ & $\begin{array}{c}\text { social guarantees for } \\
\text { rural residents }\end{array}$ & $\begin{array}{c}\text { equalization of the } \\
\text { social status of urban } \\
\text { and rural populations }\end{array}$ \\
\hline ecological & $\begin{array}{c}\text { the system of } \\
\text { ecological monitoring } \\
\text { and environmental } \\
\text { protection }\end{array}$ & ecological purity & $\begin{array}{c}\text { improving } \\
\text { environmental safety }\end{array}$ \\
\hline cultural & $\begin{array}{c}\text { system of cultural and } \\
\text { consumer services }\end{array}$ & quality of service & $\begin{array}{c}\text { improving the level } \\
\text { of cultural and } \\
\text { consumer services }\end{array}$ \\
\hline organizational & infrastructure in rural \\
& areas & quality of infrastructure & $\begin{array}{c}\text { improving the } \\
\text { quality of } \\
\text { infrastructure }\end{array}$ \\
\hline
\end{tabular}

Since "everything is necessary and accidental in different ways, everything is absolutely and relative in different ways" [3, p. 36, 68], social security can also be absolute and relative. The first case is a complete coincidence of personal and public interests and the absence of social conflicts, the second case illustrates certain contradictions between personal and public interests and allows for the presence of certain conflicts and contradictions. Since the first case is extremely rare, and the second case is the most common phenomenon, the problem of risks associated with the discrepancy between personal and public interests is a Central problem not only in the Humanities, but also in natural science. This is explained by the fact that the social security of the individual is its 
objective interest and is a need on the part of the social subject for those goods, values, resources, without which it cannot fully exist and fully develop.

In this regard, it should be recognized as timely and correct that since 2018 in the Russian Federation, the minimum wage (minimum wage) has finally been equated to the value of the subsistence minimum (VSM).

However, the mechanism for calculating the minimum wage and VSM raises serious complaints due to the fact that they are not made on the basis of direct calculation, but on the basis of indirect calculation. The indirect calculation is based on the fact that the state does not guarantee full compliance with the minimum wage and the VSM, since these values are calculated based on prices, inflation and other economic parameters of the previous period and are not indexed in any way. To begin with, the government structures cannot give clear parameters of the values under consideration for the future period. Accordingly, citizens bear the full burden of the risks of such miscalculations and do not receive part of the income declared by the state.

Direct calculation, on the contrary, provides clear guarantees to overcome the risks of non-equivalent calculations, since it is based on a genetic approach and forecasting practice. Such guarantee rights serve to overcome risks, various barriers and serve as a clearer coordination in the calculation of the values under consideration by definition $[4, \mathrm{p}$. 351].

In addition, since the subjects of social security have different socio-economic status (owners, managers, employees, pensioners, dependents, etc.), the calculation of the minimum wage and VSM must be carried out taking into account the size and structure of their total demand for specific goods and services. In other words, it is necessary to create target markets for such entities, where they "exchange" the results of their work or receive deserved (material and financial) guarantees from the state, and test such target markets as part of their constant monitoring.

It seems productive to distinguish two modalities of social security of the individual: internal and external. Internal security characterizes its physiological and psychological health. External security of the individual means that it is adapted to the environment, and the latter - to the objective needs of the inhabitants of rural and urban areas themselves. This two-way security can serve as a prototype for the concept of harmony.

The well-known thesis that a person should live in harmony with nature and the environment in modern conditions is due to the threats that such an environment poses to the ecological and, in General, social security of people. It is known that every year about 20-30 billion tons of solid waste enter the environment, and the vast majority of them remain in rural areas $[5$, p. 42]. This makes the thesis about the harmony of man and modern nature largely irrational.

At the same time, the concepts of adaptation and harmony are fundamentally different and reflect a fundamentally different state of the individual. Harmony, in contrast to adaptation, represents the highest degree of social security of the individual, since it creates the maximum degree of compliance of all levels of interests and needs in society. This harmony P. A. Florensky called syzygy at the time. Syzygy is a situation when spiritual and social alienation disappears [6, p. 39], and the individual and society are not only economically, politically, professionally, but also morally socialized, United in one organic whole.

The meaning of syzygy is revealed "in the recognition of an unconditional meaning for another being" [7, p. 791]. The essence of the behavioral aspect in the structure of social security of the individual is related to the fact that its activities are carried out freely and independently.

However, the problem of ensuring such a situation is complicated by the uncertainty of the external socio-economic and socio-cultural environment. The etiology of such 
uncertainty is due to contradictions between personal and public interests, which may not coincide in the context of a particular space and time. In practice, this means that further and more consistent institutionalization of the anti-crisis role of the state is necessary [8, p.13].

A striking example of the weakening of social security of people in modern Russian society is the chronic lag of the village from the city in socio-economic development. This is reflected in the undeveloped or unsatisfactory state of the entire infrastructure of rural territories, which is a complex of property objects and institutional superstructure" $[9, \mathrm{p}$. 445].

The understaffing of rural hospitals, dispensaries, pre-school institutions, secondary schools and other social facilities with appropriate personnel speaks for itself. Despite the current Federal programs "Zemsky paramedic", "Zemsky doctor"," Zemsky teacher", this problem is being solved very slowly. A special place in modern conditions is played by the further development of the system of social protection of the interests of rural residents.

A separate acute problem today is the impact of heterogeneity of municipalities with pronounced agricultural specialization on their spatial development. Such territories are practically absent from the list of territories of advanced development (TAD).

In the literature, it is recognized that the performance of functions for the implementation of objective socio-economic interests of rural residents by the administration of such territories is limited. As a result, "the very fact that the population lives in such territories puts them in a situation of social inequality" [10].

It is becoming increasingly obvious that the growing socio-economic inequality in the development of infrastructure in megacities and rural areas, the gap in social protection and social insurance systems, and the level of remuneration between cities and villages are becoming a key factor in the growth of macroeconomic instability[11]. And, as a consequence, the devaluation of social security of the population as a whole, and its specific categories in particular.

This is also reflected in the perceptions of rural residents themselves about the level of such social security. According to the results of a survey conducted by the authors in 2018 2019 among students of the correspondence Department of the Ural state agrarian University from among the rural residents who worked at the enterprises of the regional agro-industrial complex, the assessment of the level of social security was quite low.

As evidenced by the results of the monitoring, the evaluation of the level of social security of employees of the regional APK fluctuate around average values, but nearly onethird of agricultural enterprises showed significant violations in the field of social security staff. This applies to most of the social responsibility modules that he proposed for evaluation, among which the respondents paid particular attention to the availability of a social protection system, opportunities to receive education, working conditions and remuneration. It is interesting that the specification of the concept of social security in the form of an indicator of social security gives the lowest ratings.

Another factor in reducing the social security of Russian rural residents is the deformation of social and labor relations in the context of growing monopolization of agricultural production and unfair distribution of natural (land) rents. This is reflected in many ways. A striking example of this is the low employment of the rural population. In the Sverdlovsk region, for example, in 1843 rural localities there are 740 thousand people of the rural population, while only 37 thousand people work in the agricultural sector [12]. Last but not least this is due to the low culture of maintenance of economic and personnel security in many agricultural enterprises. There are many methods of ensuring such security $[13 ; 14]$, but most of them, unfortunately, are either not used at all, or are used inefficiently. 


\section{Conclusions}

The analysis of the state of social security of residents of rural territories of the Russian Federation allows us to draw the following conclusions:

-first, it is necessary to quickly and significantly increase the level of social security of rural residents by improving the system of social and labor relations in rural areas, the production and social infrastructure of the village and priority issues of material incentives for agricultural labor;

-secondly, it is necessary to equalize the levels of remuneration for workers in urban and agricultural production and eliminate the lag in this area of the village from the city;

- third, it is necessary to move to a direct calculation of the main financial and economic indicators in the field of remuneration of agricultural workers, taking into account the real social status, economic intensity and complexity of agricultural labor, taking into account macroeconomic instability and containing operational mechanisms for indexing the income of rural residents;

- fourth, since the Russian Federation still ranks 52nd in the world in terms of environmental cleanliness [15], urgent renovation of the natural environment and rural territories themselves is necessary, which can be implemented through more rational distribution, redistribution and use of land (natural) rents;

- fifth, it is necessary to reformat the environmental protection measures provided for by the current legislation into preventive (preventive) in nature [16]. This is quite possible if you increase the motivation of business entities in rural areas.

\section{References}

1. R.V. Goleva, Age of globalization. Research on modern global processes, 4, (2018)

2. G.A. Zavarzin, Bulletin of the Russian Academy of Sciences, 73, 7, (2003)

3. V.A. Dmitrienko, V.N. Selivanov, F.A. Sagatovsky, Collection of exercises on dialectical materialism (Tomsk, 1967)

4. A. Schueller, Business responsibility, economic calculation and competitive order. To the relation of market freedom and one's own responsibilities, Theory of economic order. The "Freiburg school" and German liberalism (Moscow: Economics, 2002)

5. Environmental problems of using natural and biological resources resources in agriculture (Yekaterinburg: Ural state publishing House. agrarian. UN-TA, 2013)

6. A.I. Matveeva, Spiritual socialization of the individual: socio-philosophical aspect (Yekaterinburg: publishing house "Banner", 2011)

7. V.S. Solovyov, Dispute about justice, (M.: "Eksmo-Press"; Kharkiv: 1999)

8. V.Zh. Dubrovsky. Institutionalization of the state's anti-crisis role, Proceedings of the Ural state University of Economics, 2 (2009)

9. D.A. Balandin, Journal of economic theory, 15, 3, (2018.)

10. V.V. Lazareva, N.Yu. Vlasova V.N. Dyachenko, Izvestiya Ural state University of Economics, 20, 1, (2019).

11. V.N. Lavrov, D.K. Stozhko, A.V. Shilovtsev, Digital economy in the transition conditions to "quick response manufacturing" model. Digital agriculture development strategy Proceedings of the International Scientific and Practical Conference (ISPC 2019), "Advances in Intelligent Systems Research" (2019) https://www.atlantis-press.com/proceedings/ispc-19/articles 
12. Fundamentals of the social state. In 2 hours (Yekaterinburg: Ural state publishing House.steward, UN-TA, Part 1, 2016.)

13. N.V. Kuznetsova, Methods of countering threats to personnel secure organizations, Izvestiya Ural. GOS. Ekonom, UN-TA, 2 (2014)

14. V.V. Vodianova, Economic security. System view (M.:GUU, 2010)

15. V.V. Ilyushko, I.V. Ilyushko, About problems of ensuring environmental safety security of the Russian Federation, Proceedings Of Velikolukskiy agricultural Academy, 4 (2018)

16. E. N. Egorova, Economic instruments for environmental protection, Proceedings of the Ural state University of Economics, 6 (2013) 